\title{
GEOPOLITICAL DISPLACEMENTS AND POPULISMS
}

\author{
Regenia Gagnier \\ University of Exeter \\ r.gagnier@exeter.ac.uk
}

In honour of the $30^{\text {th }}$ issue of a journal that has always been international, multilingual, and current in critical debate, I want to acknowledge some contemporary geopolitical displacements and challenges that are informing the literatures and cultures of today: information technology and social networking, ecological sustainability, mental health, working conditions and inequality. 1) Whereas industrial mechanization displaced the peasantry and then the proletariat of earlier modernization movements, today IT and AI are beginning to displace the middle classes. This will mean, for example, throwing lorry drivers and delivery vans out of work by replacing them with electronic automobiles, and replacing programmers, managers, clerks, and administrators by intelligent machinery. Google Pixel Buds, simultaneous translating devices worn in the ear, have ambitions to replace translators and educators. 2) Ecological unsustainability will challenge most societies living above necessity. 3) Mental health is increasingly the privatization and individuation of stress under neoliberalism (the reduction of values to those of the market). The chemico-biologization of everyday stresses amounts to a depoliticization (Fisher). 4) Despite capitalism's historical claims to reduce bureaucracy by letting the markets distribute services, bureaucracy will continue to grow in "markets" not easily commodified, such as education and health, and natural monopolies such as water, railways, and power. The production of league tables, and the ranking, self-monitoring, and management make-work that goes into them in universities is a good example of this growth in bureaucracy in market societies (Gagnier). By 2050, the worst predictions are of 50-70\% unemployment with a tiny robot-owner class immeasurably wealthy (Streeck). Without some form of universal basic income we may find that neoliberalism, having cleared away states, governments, borders, trade unions, and safety nets of any kind for the Precariat (Standing), will move us towards de- or under-institutionalized societies and local 
improvisations that are essentially ungovernable. Wolfgang Streeck persuasively paints a picture of a society of collectively incapacitated individuated individuals each battling it out in the struggle for survival. If you come from a rich enough background you might make it; if not, not.

Such current conditions, the result of global neoliberal policies since the 1970s, have given rise to a rash of populisms. At the time of writing, we see in the US and western Europe what may be the winding down of political parties with traditional left/right policies and commitments (taxing, spending, free markets) to be replaced by individual self-expression or identity politics on the internet, or politics as an expression of a group's Id. These populisms are accompanied by tendencies to blame someone other than the neoliberal regimes responsible (hence the return of overt racisms), nostalgia for simpler times, and a belief that complex problems can be solved by simple, divisive solutions. We see the rise of "Post-Truth" cultures that have nothing to do with the critical tendencies of Poststructuralism, Deconstruction, or Postmodernism. They were critical movements that critiqued Enlightenment values for their uneven application or hypocrisy. Post-truth as it is currently deployed indicates no truth, perspectivalism as mere self-interest or force (or mere bullshit (Kitcher). Perhaps most dangerous to the polis in the long term among the right-wing populist shibboleths is the idea of education itself as elitist and to be thrown out with other forms of privilege, the idea that there is no difference in democratic society between informed and uninformed opinion. It is increasingly clear that a democratic society without liberal education, preparing citizens for responsible participation, will veer between the poles of oligarchy and mob rule.

Historians date modern globalization from around 1750, when an Asian crop (sugar) was imported to Latin America to be worked by African slaves for the benefit of Europeans (Belich). Yet amidst globalization's (global trade's) forms of domination and exploitation, at least one good effect has come: global academic communities such as that represented by Kritika Kultura. These give us perspective during bad times. In terms of political languages, for example, India has historically given us some of the most positive populist movements, including the democratic populism of Gandhi, the Dalitbahujans, JP Narayan's Sampoorna Kranti "total revolution," Women's parties, and Chipko Andolan ("Tree huggers") that have formed the basis of many modern ecological movements. Yet today the Bharatiya Janata Party (BJP) under Prime Minister Narendra Modi have transformed Gandhi's economic policy of Swadeshi into the politically exclusionary and often violently oppressive Hindutva, not ideologically unlike Britain First, Brexit, or Trump's America. Modi and Trump's regimes have many similarities: Both are male-oriented and support international business and technology. India's famous Business Process Outsourcing (BPO) was originally based in Nehru's Indian 
Institutes of Technology. Forty percent of California Silicon Valley's startups in 2000 were launched by South Asians, one-half of whom were IIT graduates, yet the BJP has nothing to do with Nehru's hopes for a modern, liberal, socialist, secular, global state, polyglot, and pluralist in terms of religions and ethnicities. We have come to understand current western populisms as illiberal responses to a neoliberal unresponsiveness to people's loss of work and the dignity previously bestowed by it (Mudde; Mudde and Kaltwasser). Jan-Werner Müller thinks that populism is "a way of perceiving the political world that sets a morally pure and fully unified ... people against elites who are deemed corrupt or ... morally inferior ... . Populists are always antipluralist ... they, and only they, represent the people" (Muller, What is Populism? 19). While this seems to characterize right-wing populism in the USA, a liberal, tolerant, inclusive populism still seems possible, particularly among educated young people and journals like Kritika Kultura. 


\section{Works Cited}

Belich, James. Replenishing the Earth: The Settler Revolution and the Rise of the AngloWorld 1783-1939. Oxford UP, 2009.

Fisher, Mark. Capitalist Realism: Is There No Alternative? Zero Books, 2009.

Gagnier, Regenia. "Operationalizing Hope: The Neoliberalization of British Universities in Historico-Philosophical Perspective." Occasion: Interdisciplinary Studies in the Humanities. Special Issue "Restructuring the Humanities," edited by David PalumboLiu, volume 6, 1 Oct. 2013, pp. 1-11.

Kitcher, Philip. "Dangerous Bullshit." Los Angeles Review of Books, 2018, https:// lareviewofbooks.org/article/dangerous-bullshit/.

Mudde, Cas. "Populism in Europe: a Primer" openDemocracy, 2015, https://www. opendemocracy.net/can-europe-make-it/cas-mudde/populism-in-europe-primer.

Mudde, Cas., and Cristóbal Rovira Kaltwasser. Populism: A Very Short Introduction. Oxford UP, 2017.

Muller, Jan-Werner. What is Populism? Original Edition, U of Pennsylvannia P, 2016. Penguin, 2017.

Standing, Guy. The Precariat: The New Dangerous Class. Bloomsbury, 2011.

Streeck, Wolfgang. How Will Capitalism End? Essays on a Failing System. Verso, 2016. 